\title{
Health manpower development in Bayelsa State, Nigeria
}

This article was published in the following Dove Press journal:

Risk Management and Healthcare Policy

26 November 2012

Number of times this article has been viewed

\section{Kalada G McFubara' \\ Elizabeth R Edoni ${ }^{2}$ \\ Rose E Ezonbodor-Akwagbe ${ }^{2}$ \\ 'Department of Community Medicine, Faculty of Clinical Sciences, ${ }^{2}$ Department of Community Health Nursing, Niger Delta University, Wilberforce Island, Nigeria}

Correspondence: Kalada G McFubara Department of Community Medicine, Faculty of Clinical Sciences, Niger Delta University, Wilberforce Island, Nigeria Tel +234803710 9228

Email kalada_g_mcfubara@hotmail.com
Background: Health manpower is one of the critical factors in the development of a region. This is because health is an index of development. Bayelsa State has a low level of health manpower. Thus, in this study, we sought to identify factors necessary for effective development of health manpower.

Methods: Three methods were used to gather information, ie, face-to-face interviews, postal surveys, and documentary analysis. Critical incidents were identified, and content and thematic analyses were conducted.

Results: There is no full complement of a primary health care workforce in any of the health centers in the state. The three health manpower training institutions have the limitations of inadequate health care educators and other manpower training facilities, including lack of a teaching hospital.

Conclusion: Accreditation of health manpower training institutions is a major factor for effective development of health manpower. Public officers can contribute to the accreditation process by subsuming their personal interest into the state's common interest. Bayelsa is a fastgrowing state and needs a critical mass of health care personnel. To develop this workforce requires a conscious effort rich in common interests in the deployment of resources.

Keywords: health manpower, development, health care education

\section{Introduction}

Health is an index of development, and health manpower is a very critical resource in the development process. The concept of health manpower is varied and multidisciplinary. The Revised National Health Policy ${ }^{1}$ indicates that resources for health development, of which health manpower is a component, are important and indispensable components of effective health care delivery. By health manpower, we mean the human resources involved in administering health care to patients. Thus, if there is not adequate health manpower, there will not be effective delivery of health care, and that may slow or stall the process, either through an increased burden of ill health or through a low capacity to tackle presenting health problems. In 2006, a health manpower survey in Bayelsa State ${ }^{2}$ identified 11 different types of health personnel needed to run an effective primary health care system. These include a general practitioner, two nurses, two midwives, one dental technician, one pharmacy technician, four community health workers, six community extension workers, four environmental health workers, two health educators, two social workers, and a laboratory technician.

Bayelsa State is a core coastal region in Nigeria. It was created in 1996 from the old Rivers State. Agitation for state creation using development as a criterion has 
been the basis on which creation of states ${ }^{3}$ was done in the past (see Ayo Irikefe Panel of 1979). Apart from that, the creation of Bayelsa State was long in the making, because as far back as 1941, when the Ijaw people's league was formed, agitation for a separate Rivers Province from the then Owerri Province had begun. Meanwhile, situated in the heart of the Niger Delta, Bayelsa State is dominated by the Ijaw-speaking tribe of Nigeria. In spite of the fact that the first military governor and the first executive governor of the old Rivers State were indigenes, the area had remained developmentally marginalized. For instance, prior to the creation of Bayelsa State and despite its rich economic resources, the old Rivers State was ranked 16th among the 30 states (ie, before becoming a state in 1996) on the basis of a doctor-patient ratio of $1: 10,215^{4}$ and 19 th for its mortality rate of 197 per 1000 in children under five years..$^{5}$ Therefore, creation of Bayelsa State was seen to ensure uniform accelerated development of the area. Bayelsa State contributes $43 \%$ of the petroleum produced in Nigeria, which accounts for more than $80 \%$ of federal government revenue.

Bayelsa State has a low level of health manpower. Many health facilities cannot function because of a lack of personnel to run them. For instance, in 1999, the health manpower consisted of 44 doctors, 11 pharmacists, 54 medical laboratory technologists, and 306 nurses staffing nine general hospitals and 15 cottage hospitals in addition to over 100 primary health centers scattered across the state. Although by 2006 these figures had risen to 124 doctors, 23 pharmacists, 445 nurses, and the same number of medical laboratory technologists, the figures were still low. In fact, when the statistics are placed alongside the state's population of 1,703,358 persons (National Population Commission, 2006), the calculated doctor-patient ratio of one to 13,737 is not acceptable. Subsequent 2011 figures of 298 doctors $^{6}$ and an estimated population of 2,022,079, giving a doctorpatient ratio of one to 7000 (the World Health Organization recommends one to 5000), indicate that at least ten years after creation of the state, access to effective health care remains difficult. For instance, in almost all eight local government areas, doctors are conspicuously absent in the 168 primary health centers. Less than $6 \%$ of the primary health care centers have a general practitioner attached to them. Meanwhile, all but seven of the primary health care facilities in the state have at least one community health worker but less than $18 \%$ of them have over $50 \%$ of the required community health care worker staff. Further, just over $18 \%$ of the primary health care facilities have a nurse attached to them. This situation has left many of the citizens with no options but to consult patent medicine dealers and traditional healers as their main care providers. In this study, we aim to describe the factors necessary for effective development of health manpower.

\section{Materials and methods}

We used three methods of data collection in order to reach all stakeholders in the health manpower development process. First, face-to-face interviews were conducted with senior Ministry of Health officials to gather information on development of health services, current health manpower in the state, and other health resources, as well as training programs available for health personnel in the state. Personnel involved in this exercise included the Director of Nursing Services, the Director of Medical Services, the Head of the Public Health Laboratory Unit, the Manager of the Health Systems Development Fund, the Manager of the National Program on Immunization in Yenagoa, and the Manager of the Bayelsa Health Services Scheme (now the Bayelsa Medicaid Scheme). Second, mailed requests were sent to the three health training institutions in the state to obtain information on the performance of health care students attending those institutions. A mailed request was also sent to pioneer clinical (medical) students at Niger Delta University who were asked to supply information on place of pretertiary education. The purpose in this case was to determine the effect of school locality on health career choice by students. The management of Niger Delta University was also sent a mailed request for information on post university matriculation examination cutoff scores for their various health care programs. All the mailed requests were handdelivered during our visits to the institutions and groups. Our third method was documentary analysis of information from government sources and the WorldWideWeb. These activities were carried out between September 2009 and April 2010. To ensure internal consistency, the interviewers worked within the departments of the government health service, and held regular meetings with the principal researcher, thus ensuring external validity. Critical incidents as defined by Flanagan ${ }^{7}$ were identified, grouped as themes, and subjected to both content and thematic analysis.

\section{Results}

Information and data collected are shown in Tables 1-4. The following themes were identified and analyzed.

\section{Accreditation of programs and training institutions}

There are two stages of accreditation required for health care training institutions. One is performed by the Ministry of 
Table I Accreditation status and number of graduates from the College of Health Technology, Otuogidi, Bayelsa State, Nigeria

\begin{tabular}{llll}
\hline Program & Graduates up to 2009 & Year established & Accreditation status \\
\hline Environmental health & 53 & 2005 & Full accreditation \\
Pharmacy technicians & - & 2005 & Full accreditation \\
Dental health technician & 71 & 2005 & Visited \\
CHEW & 42 & 2005 & - \\
Junior CHEW & 59 & 2005 & - \\
Health records & 96 & 2005 & - \\
Nursing at Tombia as at 2010 & 173 & 2000 & Full accreditation \\
Nursing at NDU as at 2010 & 49 & 2001 & Full accreditation 2006 \\
Pharmacy at NDU as at 2010 & 80 & 2001 & Full accreditation 2009 \\
Medicine at NDU & & 2001 & Visitation for full accreditation in 2012
\end{tabular}

Abbreviations: CHEW, community health extension workers; NDU, Nigeria Delta University.

Education or through an agency of the ministry, such as the National Universities Commission. The other is undertaken by the professional councils, ie, the Medical and Dental Council of Nigeria, the Pharmacy Council of Nigeria, the Nursing and Midwifery Council of Nigeria, and the Medical Laboratory Council of Nigeria. The accreditation processes run by the councils have been shown to be more rigorous, and this is reflected by the difficulty in securing accreditation for health care training institutions, especially for the medical program. This seems to have become a major and chronic problem for health care training institutions in Nigeria.

The main issues hampering accreditation are lack of appropriate and adequate health care educators and appropriate training facilities, like teaching hospitals. In medicine, because the main medical school also had the problem of lack of a teaching hospital, it was expected that subsequent medical schools would take care to avoid a recurrence of the same. However, this has not been the case. The University of Benin and the Obafemi Awolowo University, at their inception, also had similar problems with getting accreditation for their medical schools. On the part of the proprietors of medical schools (which in most cases is the government), there is the political will to get their health care training institutions accredited, and this is often well demonstrated. For example, between 2005 and 2009, when accreditation visitation exercises started at the Niger Delta University College of Health Sciences, the government released approximately 900,000,000 naira $(533,000,000.00$ in $2005,77,270,000.00$ in 2007 , and $289,786,747.00$ in 2009) for laboratory equipment, reagents, office furniture, motor vehicles, and construction/renovation of buildings. Meanwhile, the status of each of the manpower training programs is as follows:

- The College of Health Technology at Otuogidi in the Ogbia local government area, which was established in 2005, by 2009 had graduated 53 environmental health officers, 71 dental health technicians, 42 community health extension workers, 59 junior community health extension workers, and 96 health record officers (see Table 1). However, the figures for middle level officers are not enough for the state.

- The School of Nursing at Tombia was established in 1999. As of 2010, the institution had graduated only 173 registered nurses. When the school was established, the goal was to graduate 400 nurses within ten years, ie, by 2012, and going by the above rate of turnover

Table 2 Performance of students in the nursing program at Nigeria Delta University, Nigeria

\begin{tabular}{|c|c|c|c|c|c|c|}
\hline \multirow[t]{3}{*}{ Academic year } & \multicolumn{6}{|c|}{ Students (n) } \\
\hline & \multicolumn{2}{|l|}{ I 00 level } & \multicolumn{2}{|l|}{200 level } & \multicolumn{2}{|l|}{ Graduates } \\
\hline & Bayelsans & Non-Bayelsans & Bayelsans & Non-Bayelsans & Bayelsans & Non-Bayelsans \\
\hline $2001 / 2002$ & 8 & 3 & - & - & - & - \\
\hline $2002 / 2003$ & 19 & 9 & - & - & - & - \\
\hline $2003 / 2004$ & 21 & 4 & 23 & 14 & - & - \\
\hline $2004 / 2005$ & 28 & 8 & 14 & 6 & - & - \\
\hline $2005 / 2006$ & 20 & 9 & 18 & 9 & - & - \\
\hline $2006 / 2007$ & 39 & 17 & 24 & 18 & 12 & 4 \\
\hline $2007 / 2008$ & 51 & 17 & 24 & 21 & 5 & 4 \\
\hline $2008 / 2009$ & 71 & 21 & 41 & 22 & 9 & 3 \\
\hline $2009 / 2010$ & - & - & - & - & 8 & 4 \\
\hline
\end{tabular}


Table 3 Performance of students in the pharmacy program at Nigeria Delta University, Nigeria

\begin{tabular}{|c|c|c|c|c|c|c|c|c|}
\hline \multirow{3}{*}{$\begin{array}{l}\text { Academic } \\
\text { year }\end{array}$} & \multicolumn{8}{|c|}{ Students (n) } \\
\hline & \multicolumn{2}{|l|}{ I 00 level } & \multicolumn{2}{|l|}{200 level } & \multicolumn{2}{|l|}{ Graduates } & \multicolumn{2}{|c|}{$\%$ progression fall rate } \\
\hline & Bayelsans & $\begin{array}{l}\text { Non- } \\
\text { Bayelsans }\end{array}$ & Bayelsans & $\begin{array}{l}\text { Non- } \\
\text { Bayelsans }\end{array}$ & Bayelsans & $\begin{array}{l}\text { Non- } \\
\text { Bayelsans }\end{array}$ & Bayelsans & $\begin{array}{l}\text { Non- } \\
\text { Bayelsans }\end{array}$ \\
\hline $200 I / 2002$ & - & - & - & - & - & - & - & - \\
\hline $2002 / 2003$ & 61 & - & - & - & - & - & - & - \\
\hline $2003 / 2004$ & 53 & 13 & 25 & 12 & - & - & - & - \\
\hline $2004 / 2005$ & 40 & 17 & Not available & Not available & - & - & - & - \\
\hline $2005 / 2006$ & 28 & 9 & 35 students & Not available & - & - & - & - \\
\hline $2006 / 2007$ & 44 & 19 & 13 & 7 & - & - & 53 & 22 \\
\hline $2007 / 2008$ & 45 & 33 & 30 & 13 & 20 & 17 & 31.8 & 31.5 \\
\hline $2008 / 2009$ & 64 & 27 & 34 & 26 & 24 & 9 & 24.4 & 21.2 \\
\hline $2009 / 2010$ & - & - & - & - & 10 & 7 & - & - \\
\hline
\end{tabular}

of graduates, the production target of 400 for the state would be difficult to realize. It is also observed that despite being rated in May 2006 by the Nursing and Midwifery Council of Nigeria as being comparable with other nursing schools in the country, the school did not present candidates for three examination seasons. The situation is even more difficult to explain when it is observed that the school was doing better (lower rate of referrals in previous examination results) until the last two examinations before 2010. Possible reasons for this are a reduction in interest of candidates for schools of nursing because there is a growing requirement for a bachelor of nursing as a minimum requirement for nurses, which the schools do not offer, or the poor educational background of candidates, and shows that there is in fact an upcoming federal government policy that would require schools of nursing to be affiliated to universities by 2012 .

- The Faculty of Nursing at the Niger Delta University is the first in any Nigerian university. It was established in 2001 and should have been able to support the School of Nursing at Tombia in realizing the state's nursing manpower production target. However, as of 2010, the faculty itself had graduated only 49 nurses in four sets, 34 of whom were Bayelsans while 15 were non-Bayelsans.

- It was expected that the first set of pharmacists would have graduated from the Niger Delta University by 2008 . Failure to graduate the students at that time was due to the faculty not being able to meet the laboratory requirements for accreditation as set out by the Pharmacy Council of Nigeria. To make up for the shortfall, laboratory classes were organized for the students at the University of Benin, and accreditation was eventually achieved in 2009. Thus, in 2010, the January and November intakes had four sets of 80 pharmacists who graduated and were entered into the profession by the Pharmacy Council of Nigeria (see Table 6). Note that two sets of 2006/2007 and 2007/2008 graduating classes were merged with the 2008/2009 set by the Pharmacy Council of Nigeria at the January induction. The Pharmacy Council of Nigeria is the statutory body that registers and regulates pharmacy practice and pharmacy education in Nigeria.

- The accreditation status of the medical program at Niger Delta University has been more complicated. The medical school has not been able to graduate its first set of doctors despite the first set of intakes being in 2001/2002. However, it is expected that these doctors will graduate in 2012. Failure to graduate earlier was due to lack of an appropriate teaching hospital, which also led to the Niger Delta University sending out its first three intakes of medical students to the Universities of Benin and Port Harcourt. The students were required to continue and complete their medical education and training in those institutions. However, those sent to the University of Benin were later sent back because the University of

Table 4 Minimum post UME score for the health care program at Niger Delta University, Nigeria

\begin{tabular}{llllll}
\hline State & Year of post UME & \multicolumn{4}{l}{ Course/cutoff scores } \\
\cline { 3 - 6 } & & Medicine & Nursing & Pharmacy & Medical laboratory science \\
\hline Bayelsa indigenes & 2009 & 101 & 75 & 75 & 53 \\
Non-indigenes & 2009 & 150 & 98 & 108 & 75 \\
\hline
\end{tabular}

Abbreviation: UME, university matriculation examination. 
Benin was found to be admitting students beyond the carrying capacity allowed by the Medical and Dental Council of Nigeria. Meanwhile, Niger Delta University has a teaching hospital, ie, the former Okolobiri General Hospital.

\section{Educational background and performance of health care students}

The educational background of most Bayelsans is poor. In other words, the foundation for indigenous health manpower development is weak. This is reflected in the performance of students in their chosen programs. For instance, Table 2 shows that between 2003/2004 and $2007 / 2008$ sessions and year-on-year, whereas the number of students who moved from the year 1 class to the year 2 class was rising for non-Bayelsa indigenes, it fell for Bayelsa indigenes, with the exception of the 2005/2006 session.

A similar observation was made for student performance in the pharmacy program (Table 3). From 2006, whereas there was a fall in the number of students who moved from the year 1 class to the year 2 class, the fall was greater yearon-year for Bayelsa indigenes.

The other issue concerning weak academic background is the concession given to Bayelsa indigenes in the admission process at the state-owned Niger Delta University. One aspect of this concession is that Bayelsa indigenes have four admission chances for every five available merit spaces (80\% versus 20\%). Table 4 shows the second aspect of the concession, whereby the admission cutoff point (minimum score) in the university aptitude examination is lower for Bayelsa indigenes as compared with their nonindigenous counterparts.

Poor educational background can be traced to the pretertiary school environment that most candidates had been exposed to earlier on. For instance, in the medical program, it is found that most of the Bayelsa indigenes in the clinical class had their secondary education in the urban and semiurban areas where educational facilities and services are better. However, $70 \%$ of Nigerians live in the rural areas. This is particularly so for the coastal and riverine communities, of which Bayelsa state is one. Thus, whereas $71 \%$ and $85 \%$ of first and second set clinical students, respectively, who are of Bayelsa State origin, had their secondary education in semiurban and urban areas, the figures are $87.5 \%$ and $100 \%$, respectively, for non-Bayelsa students. This is important to note because Bayelsa State, with Yenagoa as its capital city, is still regarded as an urban city-state while most of the other towns are rural and riverine.

\section{Health care educators}

The ratios of indigenous to nonindigenous academic staff in tertiary institutions in the state are low. For instance, the general ratio profile of indigenous academic staff to nonindigenous academic staff at the College of Health Sciences (Niger Delta University) is approximately 3:7 (Table 5). The most badly affected is the Faculty of Pharmacy, where the ratio is approximately 1:9. This deplorable picture is seen even more clearly, when the analysis is brought down to the level of departments. For example, in the pathological sciences, ie, anatomical pathology, chemical pathology, and medical microbiology, there is only one or no indigenous member of academic staff in these departments (Table 6). Indigenes account for $50 \%$ and $43 \%$ of academic staff in obstetrics and gynecology and surgery, respectively, but they are still expected to undergo postgraduate training because they lack the basic $\mathrm{PhD}$ teaching degree in their relevant fields.

\section{Discussion}

It is important for the government of Bayelsa State to develop human capital for the health system because it needs healthy people to work, create wealth, and enjoy that wealth. Thus, development of health manpower is a priority for government. The commitment of government in this regard is demonstrated by the financial resources allocated or released for the accreditation of health manpower training programs in the state. Meanwhile, the Bayelsa health system is a replica of the Nigerian health system, so is a pluralistic,

Table 5 Ratio by percentage of indigenous to non-indigenous faculty (academic) staff at the College of Health Sciences, Niger Delta University, Bayelsa State, Nigeria, as at 2010

\begin{tabular}{llllc}
\hline Faculty & Bayelsa indigenes (A) & Non-Bayelsa indigenes (B) & Total (A + B) & Percentage ratio (A:B) \\
\hline Clinical sciences & 16 & 23 & 49 & $41 \%: 59 \%$ \\
Basic medical sciences & 12 & 28 & 40 & $30 \%: 70 \%$ \\
Nursing sciences & 7 & 8 & $47 \%: 53 \%$ & $33: 91 \%$ \\
Pharmacy & 3 & 30 & 89 & 127 \\
Total & 38 & 89 & $30 \%: 70 \%$ & 15 \\
\hline
\end{tabular}


Table 6 Ratio of indigenous to nonindigenous academic staff at the College of Health Sciences, Niger Delta University, Bayelsa State, Nigeria (by departments in the medical program)

\begin{tabular}{|c|c|c|c|c|c|c|c|c|}
\hline \multirow{2}{*}{$\begin{array}{l}\text { Department } \\
\text { Indigenous } \\
\text { status }\end{array}$} & \multicolumn{2}{|l|}{ Surgery } & \multicolumn{2}{|c|}{$\begin{array}{l}\text { Community } \\
\text { health }\end{array}$} & \multicolumn{2}{|l|}{$\begin{array}{l}\text { Internal } \\
\text { medicine }\end{array}$} & \multicolumn{2}{|c|}{ Pediatrics } \\
\hline & Indigene & Non-indigene & Indigene & $\begin{array}{l}\text { Non-indigene } \\
\text { Bayelsan }\end{array}$ & Indigene & $\begin{array}{l}\text { Non-indigene } \\
\text { Bayelsan }\end{array}$ & Indigene & $\begin{array}{l}\text { Non-indigene } \\
\text { Bayelsan }\end{array}$ \\
\hline Ratio & 6 & 8 & 3 & 8 & 2 & 3 & 1 & 2 \\
\hline
\end{tabular}

heterogeneous, and complex system. The reason for this is the variety of health care providers occasioned by different types of health manpower operating in the system. Some of the health manpower can be found in the public sector, but the majority is in the private and voluntary sectors. Although manpower needs are similar in these sectors, the private sector has a peculiarity in that it also includes traditional care providers. In addition, the private sector constitutes a domain where the majority of care providers at the primary level of the health system can be found. This has led to the state neglecting its role in ensuring an effective and efficient health care system, thereby eroding the public good as a guiding principle in the allocation of resources. The absence of a common interest in the public good in the Nigerian sociopolitical system is described in the National Health Policy and Strategy as a culture of corruption and promotion of self-interest. It is demonstrated in situations where the provision of resources for developmental purposes is done only after a very long period of unnecessary waiting. Further, because most of the burden of health manpower development is at the level of cost to the individual, the cost of accessing health care within the health system is also dependent on the ability of individuals to pay for health care.

\section{The public good}

When we say that there is no consideration of the public good in the deployment of resources for health development in Bayelsa State, we mean that there is no reflection of the individual interests that are shared by most members of society. ${ }^{8}$ Although the absence of this consideration may not be peculiar to Bayelsa State, it is noteworthy that because the state is a new one, it would require a cohesive principle that unites public officers in the delivery of services if state development objectives are to be achieved. For example, in 2009, when the Faculty of Nursing Sciences at the Niger Delta University was provided with a faculty building, some buses, office equipment, and stationery, this was seen to have taken place when the dean of the faculty was a relative of the serving Commissioner for Education, and it is the Ministry of Education that supervises all educational institutions. Meanwhile, other faculties in the college with similar needs were not given the same or even similar consideration. Clearly, development of nursing manpower should not take priority over development of other health manpower.

\section{Critical mass of health manpower}

There is a need for a critical mass of health manpower, but Bayelsa State lacks the capacity to develop such a critical mass. For example, as at 2010, two years before 2012, the nursing production target of 400 at Tombia was still far from being realized. At that time, only 222 nurses $(55.5 \%$ of the target) have been produced, and this was the combined output of both the School of Nursing and the Faculty of Nursing at Niger Delta University. At the primary health care level, no health center has a full complement of the necessary staff, which may explain why there is increased effort to integrate traditional health care providers into the mainstream orthodox public health care system in the country. This is a good initiative in that it would focus on the public good in the delivery of health services, especially at the primary health care level. For example, because of their experience and knowledge of the community, traditional birth attendants (native midwives) are being trained to work at primary health centers in the management of maternal and child health problems. Community experience tends to enable practitioners to deliver services that are rich in communitarian values within the principle of common interest. Thus, it is expected that traditional birth attendants would contribute immensely to the critical mass of health workforce needed, in particular to reduce the burden of maternal and infant mortality to a minimal level.

\section{Human capital for health manpower development}

Odhiambo ${ }^{9}$ observes that we have now entered an era where human capital surpasses land, capital, and ordinary labor as sources of wealth. This is because it is only human capital that has the innate ability to accrue the basic components of development, which are skills and knowledge. Therefore, this 


\begin{tabular}{|c|c|c|c|c|c|c|c|c|c|}
\hline \multicolumn{2}{|c|}{$\begin{array}{l}\text { Obstetrics and } \\
\text { Gynecology }\end{array}$} & \multicolumn{2}{|c|}{$\begin{array}{l}\text { Medical microbiology } \\
\text { and parasitology } \\
\end{array}$} & \multicolumn{2}{|c|}{ Chemical pathology } & \multicolumn{2}{|c|}{ Anatomical pathology } & \multicolumn{2}{|c|}{ Pharmacology } \\
\hline Indigene & $\begin{array}{l}\text { Non- } \\
\text { indigene } \\
\text { Bayelsan }\end{array}$ & Indigene & $\begin{array}{l}\text { Non- } \\
\text { indigene } \\
\text { Bayelsan }\end{array}$ & Indigene & $\begin{array}{l}\text { Non- } \\
\text { indigene } \\
\text { Bayelsan }\end{array}$ & Indigene & $\begin{array}{l}\text { Non- } \\
\text { indigene } \\
\text { Bayelsan }\end{array}$ & Indigene & $\begin{array}{l}\text { Non- } \\
\text { indigene } \\
\text { Bayelsan }\end{array}$ \\
\hline 4 & 2 & 1 & 6 & I & 5 & 0 & 3 & 1 & 5 \\
\hline
\end{tabular}

means that, in a knowledge-driven economy, the development of human capital, in particular that of the health sector, should not be treated with simplistic individualism. In fact, for effective development, the health of a state must be calibrated against the skills and intellectual competence of its health workforce. In Bayelsa State, the capacity for development of this level of human capital is lean, which may be due to the educational system. Most communities are still rural and difficult to reach, including with modern educational methods and facilities. In 2009, only $40.3 \%$ of the 181 doctors in state service at the College of Health Sciences of Niger Delta University were not indigenes, the ratio of nonindigenous academic staff to their indigenous counterparts was 63\%-37\% (approximately 6:4). Meanwhile, since the college was established, none of the faculties has had an indigenous dean of professorial rank. Even at the college level, of the three provosts who have led the college in the ten years of its existence, only one is an indigene of Bayelsa State. Even so, that officer is not recognized by the Medical and Dental Council of Nigeria, the statutory body that regulates the training and practice of medicine and dentistry in Nigeria. The reason for this lack of recognition is that the officer did not train as a medical doctor but as a medical scientist. Even in departments such as surgery, obstetrics and gynecology, and anatomy and physiology, the few indigenous academic staff present are currently enrolled for higher degrees or are below the rank of senior lecturer. All these observations suggest that indigenous health manpower at higher academic levels is poor. This situation is worrying because there is no historical demonstration of an expatriate workforce building a community for indigenes. ${ }^{9}$

\section{Standardization of health manpower development}

Accreditation of training programs, especially by professional councils, is a major standardization tool for development of health manpower. Accreditation ensures that a minimum knowledge base and professional standards are maintained by manpower training institutions, and reflects the educational and professional background of the manpower of an organization. However, inability of health manpower training institutions to achieve accreditation appears to have become a major problem for health care in Nigeria. Particularly in medicine, the issue of an appropriate hospital teaching infrastructure is an ongoing problem. Teaching hospitals are complex and costly health care institutions. In fact, since the establishment of the first medical school, teaching hospitals have been shown to be difficult to establish in Nigeria. At the time of their development, the University of Benin, Obafemi Awolowo University, Delta State University, University of Ilorin, and even the leading medical school at the University of Ibadan, all had to send their pioneer medical students to other universities for clinical training before accreditation was secured from the Medical and Dental Council of Nigeria. Even where there is a hospital with many inpatients, which is an ideal environment for clinical skills training, it is still difficult to find suitable or appropriate patients for bedside teaching.

Clearly, clinical skills are acquired at the bedside under the supervision of more experienced practitioners. However, this model of health manpower training is being challenged because of the recent health care trend in the US towards shifting patient care into the community. This training model is made possible by the use of mannequin technology. For example, Osiniwo cites Hao et al, Gordon et al, and Schreiner et al, as having observed that the use of mannequins to teach clinical examination and procedural skills in a clinical skills laboratory rather than the hospital setting has been shown to be effective and well received by students and the faculty. ${ }^{10}$

We are also beginning to understand that the major responsibility for the training of health manpower cannot remain exclusively within teaching hospitals which, in fact, provide only limited experience for students. ${ }^{11}$ In this regard, the clinical skills laboratory commissioned by the Niger Delta University in 2010 has been identified as a worthwhile pioneering innovation ${ }^{12}$ for basic health manpower development in Nigeria. This is especially so considering that medical education has moved ahead in the last 20 years 
such that contact between health care students and cadavers or patients is becoming less necessary, and it has become difficult to acquire cadavers and appropriate patients for teaching purposes. Therefore, mannequins are being used to simulate the physiology, anatomy, and even disease states of the human body. Mannequin technology is based on the concept of psychomotor skills development in Bloom's taxonomy of educational objectives. ${ }^{13}$ In this regard, the development of medical education as a discipline in its own right and its accompanying innovations is contributing to the standardized development of our health manpower.

\section{Development of postgraduate health manpower}

There is no postgraduate health manpower program in Bayelsa State. However, postgraduate health manpower training is essential for an effective health manpower development policy. For example, as mentioned earlier, the lack of staff with requisite postgraduate qualifications has denied the College of Health Sciences at Niger Delta University the chance of having an indigenous medical doctor as provost. Nevertheless, the government is making efforts to ameliorate the problem. In 2000, five nurses from the Ministry of Health were sponsored by the state government for overseas training at Master's degree level. In 2004/2005, three medical doctors and two nurses from the College of Health Sciences at Niger Delta University were sponsored for postgraduate studies in the basic medical and nursing sciences. The ministry's staff development and training commitment is not receiving adequate attention. For example, in 2007, of the approximately 86 million naira earmarked for staff training and development, only 28 million naira was released, and of that amount, 89\% was spent on the training of doctors and specialists alone. ${ }^{14}$ Meanwhile, considering the limitations in availability of health care educators with appropriate qualifications, and training facilities including a teaching hospital, the need for an expanded residency program in institutions, other than the one specialists are employed in, has been suggested. ${ }^{15}$ The program is expected to send in specialist doctors who would carry out sessions in other health facilities thereby giving opportunities for trainee specialists in those facilities to have access to appropriate training. For example, the Niger Delta University teaching hospital at Okolobiri could send its specialists to the outlying hospitals, including those at Nembe, Ogbia, and Sagbama. These hospitals would have been accredited to receive trainee specialist residents at the outset. If successful, this proposal could be seen as an extension of the undergraduate community-oriented medical education program of the Medical and Dental Council of Nigeria. It would be an innovation enabling horizontal cooperation between the various health facilities rather than the present rather ineffective unidirectional vertical referral system.

\section{Conclusion}

Effective health care delivery is labor-intensive. Therefore, health manpower and planning are critical in any health system. The absence of a full complement of primary health care manpower at the health centers in Bayelsa State and lack of admission concessions given to Bayelsa indigenes at Niger Delta University suggest that Bayelsa State is still educationally disadvantaged. Even so, the state is making appreciable albeit slow progress in the development of its health manpower. Challenges in accreditation of health manpower training institutions due to limited availability of health care educators and an infrastructure, in particular a teaching hospital, are affecting this progress. According to Reich, accreditation of manpower development programs produces a workforce, the labors of which have a bearing on national and global economies as well as attracting global capital. ${ }^{16}$ Therefore, accreditation of health manpower training institutions must continue to receive high priority from government for development of effective health manpower. This is because it is the workforce of these institutions that creates the healthy citizenry to produce the wealth of the state. To ensure the development of this workforce, it is necessary to adopt a public good approach to resource allocation as a guiding principle for the official conduct of public officers. This is particularly important in order to secure the development of a critical mass of health manpower for the state. Similarly, the integration of traditional care providers into the mainstream public health system in the country would help to restore the interests of the public in the delivery of health services, especially at the primary care level. Because of their experience and knowledge of the community, traditional birth attendants who are trained to work at primary health centers in the management of maternal and child health problems can deliver services that are rich in communitarian values, of which the interests of the public are an integral aspect.

\section{Disclosure}

The authors report no conflicts of interest in this work. 


\section{References}

1. Federal Republic of Nigeria. The Revised National Health Policy and Strategy. Abuja, Nigeria: Federal Ministry of Health; 2004.

2. Ark Consult Ltd. Consultancy services for manpower survey and training needs assessment report. Health Systems Development Project II (World Bank Assisted), Government of Bayelsa State; 2006.

3. Zuofa A, Odondiri PGO. State movements. In: Alagoa EJ, editor. The Land and People of Bayelsa State: Central Niger Delta. Port Harcourt, Nigeria: Onyoma Research Publications; 1999.

4. Nte A. 21 st century medical practice: The Niger Delta perspective. Paper presented at the final year class activity. Port Harcourt, Nigeria: College of Health Sciences, University of Port Harcourt; 2002.

5. Tebepah LP. Bayelsa Health Services Scheme. Yenagoa, Nigeria: Bayelsa Ministry of Health; 2000.

6. Bayelsa State Government. Bayelsa Health, A Publication of the Ministry of Health, Yenagoa, Nigeria: Bayelsa State Government. 2011.

7. Flanagan JC. The critical incident technique. Psychol Bull. 1954;51: 327-358.

8. Saks M. Professions and the Public Interest: Medical Power, Altruism, and Alternative Medicine. London, UK: Routledge; 1995.

9. Odhiambo TR. Human resources development: problems and prospects in developing countries. Impact Sci Soc. 155:213-217.
10. Osinowo O. Paper on the Clinical Skills Laboratory presented at the College of Health Sciences Workshop, Niger Delta University, Wilberforce Island, Nigeria, March 2010.

11. World Health Organization. A Review of Determinants of Hospital Performance. Geneva, Switzerland: World Health Organization; 1994.

12. McFubara KG. Pioneering innovation in medical education: the clinical skills laboratory at NDU. Niger Delta Journal of Education. 2010:2; $45-50$.

13. Wheeler DK. Curriculum Process. London, UK: University of London Press; 1967.

14. Ministry of Finance and Budget. Approved Budget: A Budget of Sustainable Development and Empowerment. Bayelsa State, Nigeria: Budget and Control Department, Ministry of Finance and Budget; 2008.

15. Oruamabo RS. Towards Accelerated Manpower Development in Rivers State - the framework of horizontal cooperation among the local government areas. Lecture given at the Seventh State Council on Health. Port Harcourt, Nigeria: Rivers State Ministry of Health; 2004.

16. Reich RB. The real economy. Atl Mon. 1991:35-52.
Risk Management and Healthcare Policy

\section{Publish your work in this journal}

Risk Management and Healthcare Policy is an international, peerreviewed, open access journal focusing on all aspects of public health, policy, and preventative measures to promote good health and improve morbidity and mortality in the population. The journal welcomes submitted papers covering original research, basic science, clinical \& epidemio-

\section{Dovepress}

logical studies, reviews and evaluations, guidelines, expert opinion and commentary, case reports and extended reports. The manuscript management system is completely online and includes a very quick and fair peerreview system, which is all easy to use. Visit http://www.dovepress.com/ testimonials.php to read real quotes from published authors.

Submit your manuscript here: http://www.dovepress.com/risk-management-and-healthcare-policy-journal 